\title{
MHRA

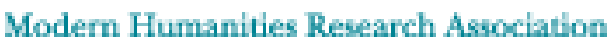

A History of English Prosody from the Twelfth Century to the Present Day. Vol. I. From the Origins to Spenser by George Saintsbury

Review by: R. B. McKerrow

The Modern Language Review, Vol. 2, No. 1 (Oct., 1906), pp. 65-70

Published by: Modern Humanities Research Association

Stable URL: http://www.jstor.org/stable/3713511

Accessed: 11/06/2014 01:39

Your use of the JSTOR archive indicates your acceptance of the Terms \& Conditions of Use, available at http://www.jstor.org/page/info/about/policies/terms.jsp

JSTOR is a not-for-profit service that helps scholars, researchers, and students discover, use, and build upon a wide range of content in a trusted digital archive. We use information technology and tools to increase productivity and facilitate new forms of scholarship. For more information about JSTOR, please contact support@jstor.org.

Modern Humanities Research Association is collaborating with JSTOR to digitize, preserve and extend access to The Modern Language Review. 


\section{REVIEWS.}

A History of English Prosody from the Twelfth Century to the Present Day. By George Saintsbury. Vol. I. From the Origins to Spenser. London: Macmillan and Co., 1906. 8vo. xvii +428 pp.

It had so long been known that Professor Saintsbury contemplated a work upon English prosody that the appearance of the first volume was almost as much a matter for surprise as for congratulation, and it may be that hope deferred had led us to expect too much. It can only be for some such reason as this that now we have the book, we are a little disappointed, for be it said at once that, whatever complaints it may seem necessary to bring against it, it is, or should be when completed, by a long way the best general history of English prosody. But we expected more-we expected that in it something at least should be done toward the settlement of metrical theory; that some at least of those questions which have puzzled all who have ever attempted the subject should be dealt with, if they could not be finally solved: and of this there is nothing. Professor Saintsbury has been faced by the same difficulties as others-though perhaps he has not perceived quite all the difficulties-and instead of triumphantly vanquishing them, he calmly ignores them. A history of English metre which refuses to investigate what really makes that metre, and which tries to evade doing so by the expedient of stringing together terms of different meaning and leaving the student to take his choice among them, can hardly expect to leave a clear understanding of the subject in the minds of its readers, even if written with a clear understanding itself. Nor can it, built on such doubtful foundations, expect to occupy the permanent and unassailable position to which the extraordinary knowledge and the critical acumen of its author should otherwise entitle it.

There was indeed little harm in refusing to discuss the ultimate nature of the difference between the 'long' and 'short' syllables out of which rhythm and metre are made, for however we may regard this difference, we should all probably agree that it exists, that it is perfectly apparent, and that in the vast majority of cases there can be no possible doubt as to which syllables are 'short' and which 'long.'

\footnotetext{
1 Nevertheless it would, we think, have been better to select some terms of less definite connotation than 'long' and 'short,' which necessarily exercise a certain influence both on the writer and on the reader.
}

M. L. R. II. 
But the next step assuredly requires discussion, for it is on a clear understanding of this that an appreciation of Professor Saintsbury's argument depends. The main thesis of his work, which is a polemic as well as a history, is that English verse is radically different from Anglo-Saxon, and not in any appreciable way developed out of it: that while the older verse depends for such rhythmical character as it possesses entirely on the presence of a certain number of all-important accented syllables, linked together by indeterminate groups of unstressed ones, the number of such syllables being variable within wide limits; in the newer verse the relation between the unstressed and stressed-or short and long -is definite. That is to say that the older verse depends on accented syllables, the newer on 'feet.'

But what are feet? This all-important question which so many have tried to solve, is never frankly and fairly dealt with. Professor Saintsbury does indeed touch on the subject from time to time in a haphazard way, and his remarks are sometimes shrewd; but we looked to him to settle it for good and all. As it is, he leaves the matter little, if any, less obscure than he found it.

On the very threshold of the question we are forced to ask: (1) Does the author consider that a line of verse, read as an ordinary intelligent person, reading it for the love of it, reads $^{1}$, can be perceived by the ear-trained or untrained - to consist of a constant, or regularly varied, number of parts, and are these parts 'feet'? or (2) Does he look on the parts as merely latent, that is to say something entirely foreign to the sound of the verse, and merely a mechanical means of counting-much as a stick might be ten inches long without there being any inches marked on the stick ${ }^{2}$ ?

Of these alternatives we feel little doubt that Professor Saintsbury would accept the first, for otherwise it is difficult to see what ground there can be for dividing a verse into feet in one way rather than another, while all such discussions as whether a Pyrrhic, a Cretic, or an Amphibrach can or cannot exist in English would be quite futile, for one could obviously make them exist at will. That Professor Saintsbury discusses these and similar questions seems to show that he does perceive, or thinks he perceives, actual parts (to call them 'divisions' would be to beg an important question) out of which a verse is made up.

But now comes the great difficulty: what precisely are these parts?

1 A theory of metre which requires that poetry should be read as it was never meant to be read, and as no one save the theorist would read it, is necessarily self-condemned; for if we allow distortion of the natural sound of a verse at will, we shall have to accept any and every theory as to its nature that has been put forward. In the note on p. 182 Professor Saintsbury recommends us to read 'scanningly,' which means, we suppose, according to his method of scansion: but surely this begs the whole question.

2 This has nothing to do with the question, also an important one, dealt with by the author on p. 299 and in an appendix, as to whether the writers had any consciousness of feet. It is sufficient that we can now, or at least Professor Saintsbury does now, divide verse into feet,- - and thus, if he will permit us to borrow from p. 168 his phrase of another matter, 'discover the positive and doctrinal principles' of work 'written when there is no evidence that any such positive or doctrinal principles existed, and all but a sertainty that they did not.' 
In one place Professor Saintsbury seems to regard them as something analogous to what $\mathrm{Mr}$ J. W. Blake meant by 'monopressures,' i.e. breath-groups-though he would, we suspect, scornfully repudiate the idea-for what else can he mean by giving us such alternative scansions as that of the fourth line of the well-known song about the monks of Ely? After scanning the line thus:

And here | we thes / muneches | sang,

he adds a footnote: 'Or if anybody prefers it,

And he $\mid$ re we $\mid$ thes mune $\mid$ ches sang,

which is, perhaps, better.'

But why the alternative, and why does it seem to Professor Saintsbury to be perhaps better? Is it not because he feels, though perhaps without actually formulating the idea, that one would not read-that nobody indeed could read-'we thes' together, that there is necessarily a pause between them? If that is so, the breath-group has at least this much to do with the foot, that portions of two breath-groups with a distinct pause between them cannot be considered as forming one foot-or at least that there is a tendency not so to consider them. Taking Professor Saintsbury's scansion in general there seems actually to be some feeling of this sort at the bottom of it, which though not in itself always affording a criterion for the division into feet, does influence the choice between possible alternatives.

But on the other hand, on p. 100 the author speaks of 'varied but harmonised time-units or feet,' while in the note on p. 82 he seems to accept 'isochronous interval' as equivalent to foot'. Now equal periods of time can form a perfectly intelligible basis for the division of a line, and so may natural pauses, but it is perfectly evident that the two are not the same, and that the 'feet' arrived at by one method will be altogether different from the 'feet' arrived at by the other. Until we can get the question settled as to what exactly Professor Saintsbury means by 'feet,' there seems to be considerable, if not insuperable, difficulty in judging between his theory and that of the ' accent-men.' That you can divide-at least on paper-any verse into feet is obvious. But until you clearly understand what these divisions are meant to represent, it is impossible to say whether or not they are legitimate.

There are many other points of theory on which it could be wished that the author had been more precise, but what we have said is already more than enough in dealing with work which so emphatically rejects theory - at least the theories of others. But has Professor Saintsbury always been at the pains to understand the views which he rejects before attacking them? The truth is perhaps that theories on metre are by no means the easiest of things to understand, and some confusion may well be excused in a writer who has so much to say of his own;

${ }^{1}$ So far as 'isochronous interval' can be said to mean anything, it seems to be the same as 'time-unit.' 
but one cannot help feeling surprised to find on the very threshold of a book in which so many attacks are made upon the theories of Guest, a passage which might almost make one suspect that he had never even read Guest's book with attention. The passage to which we refer is on pp. 8 and 9, and concerns a quotation which Professor Saintsbury gives from Dr Skeat's preface to his edition of Guest. In this extract Guest's system of marking the accentuation of words by means of an upright stroke following the accented syllable is carefully explained, and it is clearly stated that this upright stroke 'is not used to mark the division into feet as in the case of Greek and Latin verses.' Guest has

In | the hexam | eter ri | ses : the foun | tain's sil | very col | umn,

which, as Dr Skeat has made quite clear, is equivalent, if we substitute the more usual method of marking accents, to

Ín the hexámeter ríses : the fóuntain's silvery cólumn,

and Guest's marking means and implies nothing whatever besides. There are no feet, and no divisions whatever, save at the caesura.

Yet we find Professor Saintsbury, after quoting this explanation of the | mark from Dr Skeat, as referring to accent and not to footdivision, arguing as if Guest's method of indicating scansion were identical with his own, and saying that 'the Guestian division' of the line makes it anapaestic. It does nothing of the kind: there is no 'Guestian division' at all. Why, indeed, should Guest have been dividing a line into feet, anapaests or otherwise, seeing that the very point of his book is to maintain an altogether different theory of metre? We cannot help thinking that if Professor Saintsbury had given the matter a little more consideration, he would have considerably modified his remarks on Dr Skeat's scansion both in this passage and on p. 62 .

It is pleasant to turn from these matters to the aspect of the work as a history of the development of metrical form-whatever the essence of that form may be-for here there can be little but praise and thanks. From Professor Saintsbury's extraordinarily wide reading and known love of all that is best in literature we naturally expect much, and here he does not disappoint us. Step by step he follows the development of the new rhythms ${ }^{1}$, showing how at first they are more or less mixed with the older ones, as in Layamon, and how gradually they disengage themselves; while even at a very early date, we get exceptional cases of regular-too regular-metrical arrangement, as in the Ormulum ${ }^{2}$. As time goes on, in spite of fluctuation forward and backward, we gradually approach the more perfect system of

1 Whatever theory one may hold as to verse, it is impossible to deny that the rhythms are altogether different. The only question at issue can be to what, if any, extent one can be considered to have developed out of the other.

2 Although we had done with technical questions, a remark of Professor Saintsbury's concerning Orm's spelling must be noticed. He claims that it 'establishes the very important prosodic fact that doubling the consonant after an English vowel need not, though it may, make that vowel long in value.' Does the author really mean to maintain that the insertion of extra letters into the written form of a word can in any conceivable way alter its metrical value? 
which Chaucer showed the full power and range. In discussing the alliterative verse of the fourteenth century, the very considerable differences between it and that of Anglo-Saxon are well brought out, and it is remarked that the rhythm instead of being of that indeterminate kind usual in the older verse, is roughly anapaestic. When dealing with the short lyrical pieces of this period the work tends at times to become a mere catalogue of metres, by no means easy to read and scarcely possible to follow. Surely a good deal of pp. 115-138 could have been given in something approaching a tabular form. The view of Chaucer as the perfecter of the material already at his disposal rather than as the discoverer of new is well maintained, though this chapter is perhaps too largely taken up with the emphatic discussion of matters not always relevant, and not everyone will believe in the author's scansion of $K . T$. 1036,

Westward, right swich another in the opposit 1

as an alexandrine. The chaos of the fifteenth century even Professor Saintsbury can hardly render interesting as a whole, or perhaps it is that we belong to those 'non-experts' whose attention, as he says, it is difficult to fix upon it; though some of the individual pieces to which it can lay claim are among the unforgettable things of literature. What remains-that is to say practically, Wyatt, Surrey, Sackville and Spenser-is an oft-told tale, though never before told so well; and Professor Saintsbury has already dealt with it, at least in part, elsewhere. There is little to say by way of criticism, but it is surely permissible to feel surprise at finding no mention of Horestes among the dramatic work dealt with. At least two of the songs reach a standard of technical accomplishment-though perhaps not in a very high form of art-which is quite uncommon at the date. Take, as an example, the last verse of Haltersick's song:

The droum and flute playe lousteley,

The troumpet blose a mayne,

And ventrous knightes corragiousley

Do march before thear trayne:

With speare in reste so lyuely drest,

In armour bryghte and gaye ;

With hey trym and tryxey to

Thear banners they dysplaye.

But more remarkable, from the point of view of metric, is the skill with which the clumsy fourteener is handled, as for example in ll. $890-3$ :

Aboue eache thinge kepe well thy fame, what ener $y^{t}$ thou lose;

For fame once gone, they memory with fame a way it gose;

And it once lost thou shalt, in south, accomptyd lyke to be

A drope of rayne that faulyth in the bosom of the see.

1 It is not easy to believe in the line at all as it stands. It seems hardly likely that Chaucer would have spoilt his verse for the sake of explaining that westward is 'in the opposit' to eastward, and the temptation to reject 'Westward' as a foolish gloss, is very great. 
The man who by 1567 had written that last line surely deserves, in mere gratitude, some mention in a comprehensive history of English prosody.

Turberville gets perhaps somewhat less than justice. His effects indeed seldom or never quite come off, but his work gives one the impression of a much keener sense of the possibilities of rhythm than that of most of his contemporaries. The curious 'Argument to the whole discourse' of his Songs and Sonnets, with its rime-words 'Pyndara' and 'Helena' running through the whole, might have been worth a word or two. Gascoigne's Steel Glass seems nowhere to be mentioned, neither in discussing the beginning of blank verse, nor in the section dealing with Gascoigne himself. One is a little tired of seeing it stated that Gascoigne was the originator of blank verse, but that is surely no reason for ignoring him altogether.

Professor Saintsbury, rightly enough, has little to say of 'sports.' $\mathrm{He}$ does not, for example, even mention the curious 'Complaint of Cadwallader' in the Mirror for Magistrates, which 'agreeth very wel with the Roman verse called Iambus,' and he deals very lightly with the 'classical' versing of 1576 and onwards; though he promises more on the subject at another time. In a sense, it is true that the 'classical' metres are negligible-the work accomplished was, almost without exception, beneath contempt. Nevertheless the desire to find new harmonies and to perfect the old, which was in turn a cause and a symptom of the 'classical' movement, can hardly have been barren of result. Some account of the metrical study which accompanied the movement would naturally be looked for here, for surely it belongs essentially to the period of Spenser. But the author is perhaps hardly to be blamed if, as we suspect, his reason for holding this over for another volume was lest by a weary discussion he should mar the climax of that splendid name.

All students of English literature will give hearty thanks to Professor Saintsbury for this work of his, and will look forward with eager anticipation to the two volumes which are to complete it. They will regret that it is not wholly free from faults which many a lesser man than its author would certainly have avoided, but they will at the same time recognize that, taking the work as a whole, there is probably no other man who could have done it half so well.

\section{R. B. McKerrow.}

The Language of the Northumbrian Gloss to the Gospel of St Luke. By Margaret Dutton Kellum. (Yale Studies in English, xxx.) New York: Henry Holt and Co., 1906. 8vo. vi + $118 \mathrm{pp}$.

This treatise completes the series of special studies of the Northumbrian glosses to the four Gospels, inaugurated by Miss Lea's article on the language of St Mark (Anglia, vol. XVI). In 1901 Fuichsel contributed to Anglia (vol. xxIv) an examination of the gloss to 